\title{
Assessment of Heavy Metal Concentration in Soil Impacted Mining-Overburden in Enyigba, Abakaliki, Ebonyi State, Nigeria
}

\author{
${ }^{* 1}$ UCHENDU, UI; ${ }^{2}$ BIOSE, E; ${ }^{1}$ UBUOH, EA \\ ${ }^{*}$ Department of Environmental Management and Toxicology, Michael Okpara University of Agriculture Umudike, Abia State, Nigeria \\ ${ }^{2}$ Department of Environmental Management and Toxicology University of Benin, Edo State, Nigeria \\ *Corresponding Author Email: uchendu.udochukwuka@mouau.edu.ng,Tel:08034417690
}

\begin{abstract}
This study assessed the concentration of selected heavy metals (Lead and Zinc) from surrounding soil of Royal Salt mining company, Enyigba in Abakaliki LGA, Ebonyi State. Soil samples were collected from nine (9) different locations at depths of $0-15$ and $15-30 \mathrm{~cm}$. Two (2) samples were collected from each of the nine locations, making it total of eighteen (18) samples. Soil analysis carried out were particle size distribution, $\mathrm{pH}$, available Phosphorus, total Nitrogen, Organic Carbon, organic matter, Calcium, Magnesium, Potassium, Sodium, exchangeable acidity, Aluminium, effective cation exchange capacity, base saturation and two selected heavy metals, Lead $(\mathrm{Pb})$ and Zinc $(\mathrm{Zn})$. Results shows that heavy metals were highest in soil around the disposal site of mine waste. The highest value of $\mathrm{Pb}$ and $\mathrm{Zn}$ was recorded on tailing down (TD) 14.82 and $25.33 \mathrm{mg} / \mathrm{kg}$ at $0-15 \mathrm{~cm}$ depth, 7.22 and $18.93 \mathrm{mg} / \mathrm{kg}$ at $15-30 \mathrm{~cm}$ depth respectively. The accumulation of $\mathrm{Pb}$ and $\mathrm{Zn}$ at the mining site (TD) may be due to mining activities, civil, industrial/anthropogenic activities going on around the site. This study recommends regular monitoring of heavy metal concentration in soil within the mining site and their disposal site in order to conform to international standards set by the WHO.
\end{abstract}

DOI: $\underline{\text { https://dx.doi.org/10.4314/jasem.v24i7.7 }}$

Copyright: Copyright (C) 2020 Uchendu et al. This is an open access article distributed under the Creative Commons Attribution License (CCL), which permits unrestricted use, distribution, and reproduction in any medium, provided the original work is properly cited.

Dates: Received: 16 May 2020; Revised: 29 June 2020; Accepted: 07 July 2020

Keywords: Abakaliki, Enyigba, Lead, Royal Salt Limited, Zinc

Mining industries throughout history has seriously caused immense environmental pollution in industrialized and developing countries and are seen as significant sources of heavy metal contamination of soil (Obiora and Chukwu, 2016). Mining activities leaves several heaps of Lead-Zinc mine waste rocks and also brings to surface large quantities of minerals that are unstable in the weathering environment. The mine itself disrupts the landscape, and the increased surface area of the broken and crushed rocks from mining and extraction set the stage for erosion and leaching of metals to the environment (Ogbonna et al., 2013). The release and contamination of soils with heavy metal through industrial effluents especially mining is of major environmental concern because the accumulated metals may adversely affect soil ecology, agricultural production, product quality, animal and human health as well as ground water quality (Adriano et al., 2001). Indeed, unlike organic contaminants, most heavy metals are not biodegradable and therefore total concentrations and ecotoxicological effects persist for very long periods after their introduction to the soil, they accumulate in organisms and cause numerous diseases and disorders (Eze and Chukwu, 2011). Over recent decades, the annual worldwide release of heavy metals reached 783,000 metric tons of Lead and 1,350,000 metric tons of Zinc (Singh et al.,
2003). Because of its environmental significance, studies to determine risk caused by metal levels in soil on human health and forest ecosystems have attracted attention in recent years (Arantzazu et al., 2000; Krzyztof et al., 2004). It has been known that LeadZinc mining Leads to considerable heavy metal pollution in the soil of the surrounding area and thus, investigation of heavy metal content in soils and evaluation of the potential risks and human health risks from heavy metals in the waste dumpsite of this mining area are of vital importance to better understanding. Studies so far on the impacts of mining in Abakaliki Lead-Zinc mining area have focused mainly on water and plants metal load (Edeogu et al., 2007: Eze and Chukwu, 2011), their health and environmental impact. The impacts of Lead-Zinc mining on plant physiology, anatomy and biochemistry are also available in local and international literatures (Ogbonna et al., 2013). The health impacts of heavy metal contamination are well documented. However, there is scarcity of literature on the impacts of Lead-Zinc waste on the fertility indices of the soil, soil microbial activity and their ecological impacts. The concentration of heavy metals in soil solution plays a critical role in controlling the availability of ions to plant. The solubility and therefore the bioavailability of heavy metal ions vary

*Corresponding Author Email: uchendu.udochukwuka@mouau.edu.ng,Tel: 08034417690 
widely because many factors affecting metal availability such as soil $\mathrm{pH}$, clay content and organic matter content (Davies et al., 2005; Friedland et al., 1992). It has been found that soils contaminated by heavy metals tend to exhibit reduced porosity, poor hydraulic conductivity and high rate of compaction (Udom et al., 2004). Heavy metal has been shown to affect the soil actual content, plant and soil microbial function. Therefore, it is important to assess the degree of Lead-Zinc mining waste in this study area. This study is relevant to understand the effects of such heavy metals on the fertility indices of the soil and in comparing the degree of contamination between tailing down (TD) and refuse dump site (RDS). This aim of this research is to assess the concentration of selected heavy metals $(\mathrm{Pb}, \mathrm{Zn})$ on the fertility indices of the soil from Lead-Zinc mining at Royal Salt Limited, Enyigba in Abakaliki LGA, Ebonyi State.

\section{MATERIALS AND METHOD}

The Study Area: The Abakaliki mining area lies between $06^{\circ} 08^{\prime} \mathrm{N}$ and $06^{\circ} 24^{\prime} \mathrm{E}$ and falls within the lower region of the Benue Trough. It includes Abakaliki town and the highly mineralized rural communities (Amagu, Ameri, Enyigba and Ameka) which are about 14 kilometres south of the metropolis (Abakaliki) (Chukwuma, 1993). The area is underlain with poorly bedded shales of the Abakaliki shale age and deposits of galena $(\mathrm{PbS})$ and sphalerite $(\mathrm{ZnS})$ occur as veins and lodes in the oldest exposed sequence of the Abakaliki Basin within which the highly mineralized rural community are located. The mining areas are inhabited by mostly agrarian people with artisanal Lead-Zinc mining as secondary operation. The Benue trough is one of the known major areas with $\mathrm{Pb}-\mathrm{Zn}$ deposit in West Africa. Abakaliki, especially the Enyigba area which is about $14 \mathrm{~km}$ south of Abakaliki, is overlain with tropical rocks which constitute gneisses, granites, shales, sphalerite and crustal rocks (Berti and Cunningham, 1997). The prevailing climate is laden with high rainfall, high temperature, high atmospheric humidity and precipitation usually exceeding evapotranspiration for more than half the year. The Enyigba Lead and Zinc mine was intermittently mined for Lead from 1925. Mining operations ceased due to low economic returns as well as the 1967 - 1970 Nigerian Civil War that badly affected the industry. This Abakaliki Lead-Zinc mining area, comprising of Ameka, Ameri and Enyigba provide the inhabitants with economic sustenance next to agriculture. With the discovery and exploration of solid minerals in Abakaliki division of old eastern Nigeria, in the 1940s, artisan mining activities have become significant occupation among the inhabitants, to the extent that all the households within the mining areas are involved in artisanal mining.

Sample Collection and Analysis: Soil samples were collected at depth $0-15 \mathrm{~cm}$ and $15-30 \mathrm{~cm}$ from a mine waste dumpsite known as tailing down (TD) and a refuse dumpsite (RDS) within the premises of Royal Salt Limited (Mining Division) and a non-mining area 100 metres away from the company which was used as the control site (Ctrl) using a soil auger. Two (2) soil samples, 5 meters apart from Nine (9) different collection points were taken making it a total of 18 samples. The samples were taken to the laboratory; air dried, sieved and kept in a clean and dry place for analysis and the determination of particle size distribution, texture, some chemical properties and selected heavy metals. Soil samples were analysed in the laboratory using standard laboratory procedures for some selected physical and chemical properties as well as heavy metal concentration of Lead and Zinc.

Particle Size Distribution was determined using the hydrometer method by Bouyoucus (1962), Soil pH was determined both in water and $1 \mathrm{~N} \mathrm{KCl}$ in $1: 2.5$ soil water ratio using the glass electrode meter as described by Thomas (1996), Available Phosphorus in soil was determined using Bray-2 method as described by Bray and Kurtz (1945), Total Nitrogen in the soil sample was determined by Kjedahl digestion method as described by Bremmer and Mulvaney (1988), TEB (Calcium, Magnesium, Potassium, Sodium) were determined using $1 \mathrm{~N}$ NH4 AOC method, The exchangeable acidity was determined by $1 \mathrm{~N} \mathrm{KCl}$ Extraction by (Mclean 1982), Effective cation exchange capacity was determined or calculated by the summation of total exchangeable bases (TEB) (Ca, $\mathrm{Mg}, \mathrm{Na}, \mathrm{K}$ ) and Exchangeable Acidity (EA), Soil organic carbon was determined by Walkey and Black Wet - Oxidation Method as modified by Nelson and Sommers (1998), Lead and Zinc were determined using the digestive method of A.O.A.C. (2002). Data analysis on the soil physico-chemical properties, heavy metal distribution in the soil samples were subjected to analysis of variance (ANOVA), while the mean values were separated using the Least Significant Difference (LSD) at $\mathrm{P}<0.05$.

\section{RESULTS AND DISCUSSION}

The mean effect of the particle size analysis of soils at different depth and location are shown in Table 1 below. The result showed that sand particles were significantly $(\mathrm{P} \leq 0.05)$ high at the Lead and Zinc tailing down (TD) with $77.7 \%$ at $0-15 \mathrm{~cm}$ and $74.17 \%$ at $15-$ $30 \mathrm{~cm}$ depth, followed by $67.90 \%$ and $64.70 \%$ at 0 $15 \mathrm{~cm}$ and $15-30 \mathrm{~cm}$ respectively.. 


\begin{tabular}{|c|c|c|c|c|c|c|c|}
\hline & Control & & RDS & & TD & & LSD (0.05) \\
\hline & $0-15 \mathrm{~cm}$ & $15-30 \mathrm{~cm}$ & $0-15 \mathrm{~cm}$ & $5-30 \mathrm{~cm}$ & $0-15 \mathrm{~cm}$ & $15-30 \mathrm{~cm}$ & \\
\hline Sand (\%) & 67.9 & 64.7 & 46.9 & 38.43 & 77.7 & 74.17 & 1.75 \\
\hline Silt (\%) & 15.87 & 14.77 & 27.7 & 32.43 & 10.57 & 11.57 & 2.32 \\
\hline Clay (\%) & 16.23 & 20.37 & 25.47 & 29.13 & 11.73 & 14.27 & 1.52 \\
\hline Texture & SL & SCL & SCL & SCL & SL & SL & \\
\hline
\end{tabular}

Table 2: Mean Effect of Chemical Properties of Soils at Different Depth and Location.

\begin{tabular}{|c|c|c|c|c|c|c|c|}
\hline Parameters & Control & & RDS & & TD & & LSD (0.05) \\
\hline & $0-15 \mathrm{~cm}$ & $15-30 \mathrm{~cm}$ & $0-15 \mathrm{~cm}$ & $15-30 \mathrm{~cm}$ & $0-15 \mathrm{~cm}$ & $15-30 \mathrm{~cm}$ & \\
\hline $\mathrm{pH} \mathrm{H}_{2} \mathrm{O}$ & 5.5 & 4.83 & 5.73 & 5.3 & 5.47 & 4 & 0.13 \\
\hline pH KCl & 4.43 & 3.43 & 4.76 & 4.36 & 4.4 & 4.33 & 0.16 \\
\hline Av. P & 22.03 & 15.77 & 25.07 & 18.07 & 24.13 & 18.73 & 1.64 \\
\hline $\mathbf{N}$ & 0.129 & 0.108 & 0.178 & 0.133 & 0.084 & 0.061 & 0.01 \\
\hline OC & 1.47 & 1.23 & 1.99 & 1.6 & 1.07 & 0.78 & 0.117 \\
\hline OM & 2.54 & 2.12 & 3.43 & 2.76 & 1.85 & 1.37 & 0.185 \\
\hline $\mathrm{Ca}$ & 4 & 2.53 & 5.8 & 3.06 & 4.46 & 2.13 & 0.63 \\
\hline Mg & 1.96 & 1.23 & 3.1 & 2.3 & 2.1 & 1.06 & 0.2 \\
\hline $\mathbf{K}$ & 0.238 & 0.17 & 0.372 & 0.195 & 0.245 & 0.184 & 0.022 \\
\hline $\mathbf{N a}$ & 0.193 & 0.155 & 0.39 & 0.215 & 0.61 & 0.39 & 0.029 \\
\hline EA & 1.32 & 1.72 & 1.19 & 1.41 & 1.33 & 1.49 & 0.06 \\
\hline $\mathrm{Al}^{3+}$ & 0.21 & 0.43 & 0.17 & 0.37 & 0.26 & 0.44 & 0.04 \\
\hline ECEC & 7.72 & 5.81 & 10.85 & 7.18 & 8.89 & 5.2 & 0.61 \\
\hline BS & 82.87 & 70.37 & 88.97 & 80.43 & 84.99 & 71.7 & 1.78 \\
\hline
\end{tabular}

$R D S=$ Refuse dumpsite, $T D=$ Tailing down, $L S D=$ Least Significant Difference, $A v . P=$ Available; Phosphorus, $N=$ Nitrogen, OC $=$ Organic Carbon, $O M=$ Organic Matter, $C a=$ Calcium, $M g=$ Magnesium, $K=$ Potassium, $N a=$ Sodium, EA = Exchangeable Acidity, Al3 $+=$ Aluminium, ECEC $=$ Effective Cation Exchange Capacity, BS $=$ Base Saturation.

The lowest value of sand was obtained on the sample from RDS (refuse dumpsite) with $46.90 \%$ at $0-15 \mathrm{~cm}$ and $38.43 \%$ at $15-30 \mathrm{~cm}$. Silt and clay particles of the sample soil followed a reverse trend. Thus the lowest values of silt and clay were recorded on the sample from TD, $10.57 \%$ silt at $0-15 \mathrm{~cm}$ and $11.73 \%$ at 15 $30 \mathrm{~cm}$ depth, while the highest value on silt and clay were obtained on sample from RDS $27.7 \%$ silt at 0 $15 \mathrm{~cm}, 25.47 \%$ silt at $15-30 \mathrm{~cm}$ and $32.80 \%$ clay at 0 $15 \mathrm{~cm}$ and $29.13 \%$ clay at $15-30 \mathrm{~cm}$. The increase in sand and decrease in silt and clay particles may be attributed to the mining activities, civil and industrial anthropogenic activities around the mining site which may lead to loss of biomass from the soil surface (Pehlivan et al., (2009). The result is in agreement with Abimbola et al., 2003, where they noticed an increase in sand particles as a result of mining activities and increase in heavy metals (Lead and Zinc) deposition of soil surface. However, Ogbonna et al, 2013 reported no change on sand, silt and clay particles on the sol tested from mining site. The mean effect of the chemical properties of soils at different depth and location are shown in Table 2 below. The result showed that $\mathrm{pH}$ of the sampled area was generally low, showing that the soil is acidic in nature. $\mathrm{pH}$ value of the studied locations ranges from $5.73-4.70$. The highest $\mathrm{pH}$ value was recorded on RDS 5.73 at $0-15$ $\mathrm{cm}$ followed by 5.5 from the control site while the lowest value on $\mathrm{pH}$ was recorded from the sample collected at TD 5.47, at $0-15 \mathrm{~cm}$ and 4 at $15-30 \mathrm{~cm}$. The result shows a significant difference $(\mathrm{P} \leq 0.05)$ on the
$\mathrm{pH}$ across the tested areas. The lower $\mathrm{pH}$ recorded on the mining site may be due to the long-term toxic effect of the mining activities at the area as reported by Obiora and Chukwu, (2016).

Available phosphorus (Av. P) shows a significant increase as shown on table 2. The highest value on Av. $\mathrm{P}$ was recorded on samples collected from refuse dumpsite RDS $(25.07 \mathrm{mg} / \mathrm{kg})$ at $0-15 \mathrm{~cm}$ followed by $24.13 \mathrm{mg} / \mathrm{kg}$ from TD at $0-15 \mathrm{~cm}$, the lowest value of Av. P was obtained from the control site $(22.03 \mathrm{mg} / \mathrm{kg})$. There is a decrease in the Av. P down the depth. Total Nitrogen values ranges from $0-178-0.84 \%$ at $0-15 \mathrm{~cm}$. The result shows a significant difference $(\mathrm{P} \leq 0.05)$ in Nitrogen. Highest value on Nitrogen was obtained on the samples collected from TDS, $0.178 \%$ at $0-15 \mathrm{~cm}$ and $0.133 \%$ at $15-30 \mathrm{~cm}$ depth, followed by $0.129 \%$ from control site (Ctrl) at $0-15 \mathrm{~cm}$ and $0.108 \%$ at 15 $30 \mathrm{~cm}$ depth. The lowest value was recorded on sample collected from TD $0.084 \%$ at $0-15 \mathrm{~cm}$ and $0.061 \%$. The decrease in Nitrogen at TD may be due to the removal of biomass and the toxicity of the heavy metal around the mining site (Leyval and Joner, 2001). Organic Carbon (OC) and Organic Matter (OM) followed the same trend, there is a significant increase $(\mathrm{P} \leq 0.05)$ on the organic carbon and organic matter content of the soils. The highest value on $\mathrm{OC}$ and $\mathrm{OM}$ were recorded on RDS (1.99\%) and (3.43\%) followed by Ctrl $1.47 \%$ and $2.54 \%$ at $0-15 \mathrm{~cm}$ while the lowest value of $\mathrm{OC}$ and OM was obtained from RDS with OC (1.07\%) and OM $(1.85 \%)$. The result showed a significant difference 
$(\mathrm{P} \leq 0.05)$ on the basic cations present in the soil, the $\mathrm{Ca}$ values ranges from 5.80-4.00. The highest value of $\mathrm{Ca}$ was obtained from the samples collected from RDS $5.80 \mathrm{Cmol} / \mathrm{kg}$ at $0-15 \mathrm{~cm}$ and $3.06 \mathrm{Cmol} / \mathrm{kg}$. Followed by $4.40 \mathrm{Cmol} / \mathrm{kg}$ from the mining dumpsite at $0-15 \mathrm{~cm}$ depth and $3.06 \mathrm{Cmol} / \mathrm{kg}$ at $15-30 \mathrm{~cm}$ depth while the samples from control gave the lowest value on $\mathrm{Ca}$ $(4.00$ and $2.53 \mathrm{Cmol} / \mathrm{kg})$ at $0-15 \mathrm{~cm}$ and $15-30 \mathrm{~cm}$ respectively. The result followed the same trend on Magnesium $(\mathrm{Mg}$ ) and Potassium $(\mathrm{K})$ values. The highest value on $\mathrm{Mg}$ and $\mathrm{K}$ was obtained on the samples from RDS 3.1 and $0.372 \mathrm{Cmol} / \mathrm{kg}$ followed by TDS 2.1 and $245 \mathrm{Cmol} / \mathrm{kg}$ while the control gave the lowest value of $\mathrm{Mg}$ and $\mathrm{K}(1.96$ and $0.238 \mathrm{Cmol} / \mathrm{kg})$. There is a significant difference $(\mathrm{P} \leq 0.05)$ on the $\mathrm{Ca}$, $\mathrm{Mg}$ and $\mathrm{K}$ results obtained across the three (3) locations apart from the samples from the refuse dump which $\mathrm{Ca}, \mathrm{Mg}$ and $\mathrm{K}$ values are moderate, the other two locations, mining site and control has low $\mathrm{Ca}, \mathrm{Mg}$ and $\mathrm{K}$; The moderate values of the cations on the refuse dump may be attributed to the decomposition and mineralization of organic material or waste on the dumpsite while the decrease in $\mathrm{Ca}, \mathrm{Mg}$ and $\mathrm{K}$ at $\mathrm{TD}$ may be due to the effect of mining activities and accumulation of heavy metals (Lead and Zinc) on the mining area (Aydinalp and Marinova, 2003). The result showed an increase $(\mathrm{P} \leq 0.05)$ on Sodium $(\mathrm{Na})$ concentration at TD $(0.610 \mathrm{Cmol} / \mathrm{kg})$ followed by the sample collected at RDS $(0.390 \mathrm{Cmol} / \mathrm{kg})$. The result also showed trendy values on the exchangeable acidity (EA), Aluminium $\left(\mathrm{Al}^{3+}\right)$, effective cation exchange capacity (ECEC) and base saturation (BS) concentration of the soil across all sample locations. Though EA and $\mathrm{Al}^{3+}$ decreases from RDS to TD, thus the EA result can be presented in this order $\mathrm{TD}>$ Control $>$ RDS, $1.41>1.32>1.19 \mathrm{Cmol} / \mathrm{kg}$ at $0-15 \mathrm{~cm}$. The highest value on ECEC and BS were recorded on the sample collected from refuse dump, ECEC $(10.85 \mathrm{Cmol} / \mathrm{kg})$, BS $(88.97 \%)$ while the lowest value was recorded on the sample collected from control, ECEC $(7.72 \mathrm{Cmol} / \mathrm{kg})$, BS $(82.87 \%)$. The decrease recorded on the chemical properties of the soil collected at the mining dumpsite is a clear indication that Lead $(\mathrm{Pb})$ and Zinc $(\mathrm{Zn})$ contamination has negative effect on the chemical properties of soil which will in turn Lead to low fertility status of the soil around the mining site (Aydinalp and Marinova, 2003).

\begin{tabular}{|c|c|c|c|c|c|c|c|}
\hline Heavy Metals & Control & & RDS & & TD & & LSD (0.05) \\
\hline & $0-15 \mathrm{~cm}$ & $15-30 \mathrm{~cm}$ & $0-15 \mathrm{~cm}$ & $15-30 \mathrm{~cm}$ & $0-15 \mathrm{~cm}$ & $15-30 \mathrm{~cm}$ & \\
\hline Zn & 0.26 & 0.07 & 4.69 & 2.29 & 25.33 & 18.93 & 2.75 \\
\hline $\mathbf{P b}$ & 0 & 0 & 0.19 & 0.12 & 14.82 & 7.22 & 2.94 \\
\hline
\end{tabular}

From table 3 above, the highest value of $\mathrm{Pb}$ and $\mathrm{Zn}$ was recorded on the sample 14.82 and $25.33 \mathrm{mg} / \mathrm{kg}$ at 0 $15 \mathrm{~cm}$ and 7.22 and $18.93 \mathrm{mg} / \mathrm{kg}$ at $15-30 \mathrm{~cm}$. Followed by the sample collected from refuse dump $\mathrm{Pb}$ $(0.19 \mathrm{mg} / \mathrm{kg}), \mathrm{Zn}(4.69 \mathrm{mg} / \mathrm{kg})$ at $0-15 \mathrm{~cm}$ and 0.12 and $2.29 \mathrm{mg} / \mathrm{kg}$ at $15-30 \mathrm{~cm}$. The accumulation of Lead and Zinc at TD may be due to mining activities, civil, industrial/anthropogenic activities going on around the site. This result is in agreement with the findings of Abimbola et al., (2003), Clark, (1992), Pehlivan et al., (2009), where they reported an increase in the $\mathrm{Pb}, \mathrm{Zn}$ concentration on the soil from the mining sites. The increase recorded on the heavy metals $(\mathrm{Pb}$ and $\mathrm{Zn})$ at the mining site is a clear indication that the soil around the Enyigba mining site is highly polluted by Lead and Zinc as a result of mining the two selected heavy metals in that area (Edeogu et al., 2007)

Conclusion: This study showed that there was a significant difference in the level of Lead and Zinc content of soil from tailing down indicating that the soil is polluted due to the mining activities and disposal of mine waste. The high level of Lead and Zinc in the tailing down also affects the organic matter content of the soil hence, affecting the structural stability and productivity of the soil. This study therefore recommended the need for phytoremediation and development of an optimum land use plan for maximizing agricultural production.

\section{REFERENCES}

Abimbola, AF; Olatunji, AS; Odewande, AA (2003). Heavy metals contents of soils and sediments in five selected industrial estates in Southwestern Nigeria. NMGS Conference paper, Itakpe. Book of Abstract, pp. 36.

Adriano, DC (2001). Trace Elements in Terrestrial Environment; Biogeochemistry, Bioavailability and risks of metals (Springer, New York.)

AOAC. (2002) Official Methods of Analysis association of official analytical chemists. $16^{\text {th }}$ Edition. William Hormitz, pp. 9-12.

Arantzazu, U; Vega, M; Angul, E (2000). Deriving ecological risk-based soil quality values in the Barque country. The Science of the Total Environment. 247:279-284 
Aydinalp C; Marinova S (2003) Distribution and Forms of Heavy Metals in Some Agricultural Soils. Polish Journal of Environmental Studies. 12(5):629-633.

Berti, WR; Cunningham, SD (1997). In-place inactivation of Lead in Lead-contaminated soils. Environ. Sci. Technol. 31: 1359-1364.

Bouyoucus, GH (1962). A recalibration of the hydrometer making mechanical analysis of soil. Agric. Journal 4: pp. 434-438

Bray, RH; Kurtz, LT (1945). Determination of Total Organic and available forms of phosphorous in soils. Soil Science Journal, 59:39-45

Bremmer, JM; Mulvaney, CS (1988). Total Nitrogen; Method of Soil Analysis Part 2 A. L. pp. 395-624

Chukwuma, C (1993). Cadmium, Lead and Zinc from Terrestrial plants in the Enyigba Lead and Zinc Mine: Search for a monitoring plant species in Trace Element distribution. J. Bull. Environ. Contam. Toxic. 51, 665-671.

Clark, R (1992). Marine Pollution. Oxford, UK: Cleavendo Press, pp. 61-79. CODEX Alimentarius Commission. (1994). CX/FAC 95/18/11. Discussion Paper on Lead. $22^{\text {nd }}$ Session, March, 1995.

Davies BE; Bowman C; Davies TC; Sellinus O (2005). Medical Geology: Perspective and

prospects. Essent. Med. Geol., Elsevier Inc., Pp. 1-14.

Edeogu CO; Ekuma CE; Okaka AN; Ezeonu FC; Uneke CJ; Elom SO (2007). Public health significance of metals concentration in soils, water and staple foods in Abakaliki South Eastern Nigeria. Trends in Applied Science Research 2: $439-444$

Eze H; Chukwu E (2011). Small scale mining and heavy metals pollution of agricultural soils: the case of Ishiagu mining district, South Eastern Nigeria. Journal of Geology and Mining Research vol.3(4) pp.87-104

Friedland, AJ; Bradley, WC; Miller, EK; Herrick, GT; Siccama, TG; Johnson, AH (1992). Decreasing Lead levels in the forest floor of the North-Eastern USA. Ambio 21:400-403.
Krzyztof, L; Danutta, W; Irena, K (2004). Metal contamination of farming soils affected by industry. Environment International. 30(2) 159165.

Leyval C; Joner EJ (2001). Bioavailability of heavy metals in the mycorrhizosphere, In G.R. Gorban, W.W. Wenzel, E. Lombi (Eds). Trace elements in the rhizosphere, CRC, Boca Taton, FL.Pp. 165185

Mclean (1982). Physical and chemical methods of soil and water analysis: Soil Bulletin No 10

Nelson, DW; Sommers, IE (1998). Total organic carbon/organic matter Determination. Methods of Soil Analysis Part 3. Soil Science, soil organic carbon. American Book Series pp 346-351

Ogbonna CE; Adinna EN; Ugbogu OC; Otitoju O (2013). Heavy metal concentration and physicochemical properties of soil in the LeadZinc mining area of Ishiagu, Nigeria. Journal of Biodiversity and Environmental Science 3(10), 61-69.

Pehlivan, E; Özkan, AM; Dinç, S; Parlayici, S (2009). "Adsorption of $\mathrm{Cu}^{2+}$ and $\mathrm{Pb}^{2+}$ ion on Dolomite Powder," Journal of Hazardous Materials. 167 (1-3): 1044-1049.

Obiora SC; Chukwu, TC (2016). Davies. Heavy metals and health risk assessment of arable soils and food crops around $\mathrm{Pb}-\mathrm{Zn}$ mining localities in Enyigba, South eastern Nigeria, J. Afr. Earth. Sci. $116182-189$

Singh, OV; Labana, S; Pandey, G; Budhiraja, R; Jain, RK (2003). Phytoremediation: an overview of Metallic ion Decontamination from Soil. Applied Microbiology and Biotechnology. 61: 405-412.

Thomas, GR (1996). Electrometer pH determinations. John Willey and Sons Inc. New York.

Udom, BE; Mgbawa, JSC; Adesodun JK; Agbim N (2004). Distribution of Zinc, copper, cadmium and $\mathrm{Pb}$ in a tropical utisol after long-term disposal of savage sludge: Environment International 30 467-470. 